\title{
A New Hybrid Decision Making Approach for Housing Suitability Mapping of an Urban Area
}

\author{
Mithat Zeydan $\mathbb{D D}^{1}{ }^{1}$ Bülent Bostanc1, ${ }^{2}$ and Burcu Oralhan ${ }^{3}$ \\ ${ }^{1}$ Industrial Engineering, Erciyes University, Kayseri 38030, Turkey \\ ${ }^{2}$ Geomatics Engineering, Erciyes University, Kayseri 38280, Turkey \\ ${ }^{3}$ Economics and Administrative Sciences, Nuh Naci Yazgan University, Kayseri 38170, Turkey
}

Correspondence should be addressed to Mithat Zeydan; mzeydan@erciyes.edu.tr

Received 18 May 2018; Revised 23 August 2018; Accepted 9 September 2018; Published 15 October 2018

Academic Editor: Ana C. Teodoro

Copyright (C) 2018 Mithat Zeydan et al. This is an open access article distributed under the Creative Commons Attribution License, which permits unrestricted use, distribution, and reproduction in any medium, provided the original work is properly cited.

\begin{abstract}
In urban planning, housing evaluation of residential areas plays a critical role in promoting economic efficiency. This study produced an evolutionary-based map through the combination of hybrid Multicriteria Decision Making (MCDM) and Geographical Information System (GIS) by assessing suitability of housing location. Suitable locations were modelled and determined with the present study from very low suitability to very high suitability. In the first stage, Fuzzy DEMATEL (the Decision Making Trial and Evaluation Laboratory) and Covariance Matrix Adaptation Evolutionary Strategy (CMA-ES) under fuzzy conditions as a subjective and an objective (model-based) technique, respectively, were employed to find the weights of criteria which are critical part of decision making. In the second stage, housing evaluation map for these two approaches was drawn and their performances were classified and measured with WLC (Weighted Linear Combination) method. 29 criteria determined were prioritized as per judgment of urban planning and real estate experts for Fuzzy DEMATEL and CMA-ES. After having been coded to MATLAB for obtaining optimum weights in CMA-ES, all collected data for 160 houses were mapped as vectorial (positional) and transformed to raster (pixel) data by getting entered in ArcGIS 10.4 software. We achieved CMA-ES-WLC maximization values for 104 alternatives with (positive value) 65\% performance, but we obtained FDEMATEL-WLC maximization values for 56 alternatives with (negative value) 35\% performance. WLC values calculated with CMA-ES and FDEMATEL weights allowed us to conclude that the houses with the highest suitability in terms of investment are in Alpaslan, Köşk, and Melikgazi streets. The result shows that the methodology used in the application of this study performed in Turkey is an important and powerful technology in providing decision support for spatial planning.
\end{abstract}

\section{Introduction}

As urban population living in cities increases rapidly, it is crucial to preserve environmental values and improve quality of urban service and quality of life. In this context, the concept of the land use and development of urban areas in accordance with this goal is one of the topics discussed in the urbanization literature [1]. Land use planning includes decisions about interdependent and multilayered issues affecting air and water quality, access to transportation options, economic viability, and quality of life [2-5]. Creating planned areas that include types and uses of buildings and places to meet needs of residents' daily lives has a critical viewpoint. Primary types of planning areas that need to be supplied to residents by municipalities are classified as residential, commercial, industrial, green, and agricultural areas [6,7]. Land use, once considered as a local environmental issue, is now regarded as a driving force of global importance. Regulation of land use is the main function of local governments whose planning departments monitor many regulations related to land acquisition, including land master planning, transport, housing, economic development, and reconstruction [8]. Suitability evaluation is of considerable use for land use planning and development [9]. The development of land use policies and related coordination in Turkey has come to the fore after 1980s. Urban Land Use and Planning Act was renovated in 1985 [10] since migrations, urban population growth, increasing population density in city center, infrastructure problems, use of fertile agricultural land, industrialization, and other factors reveal necessity of producing policies for 
land use planning [11]. Regional, environmental, master, and implementation plan hierarchy for physical planning was foreseen. The law was designed in order to ensure that the settlements and the structures in these places are in accordance with the plan, science, health, and environment conditions $[10,12]$. Policies made for this purpose generally bring temporary solutions together with socially meaningful housing and social and spatial-functional injustice accompanied by the release of slum dwellings on one hand. In general, it has been observed that applications for urban land use and housing production are primarily due to technical and legal problems of ownership structure and fail to produce sustainable land use and housing policies [13]. The basic aim of housing policies is to get at the price that they will be able to pay for "good and adequate housing" for entire segment of society from lowest income group to top income group. Nevertheless, housing problem (especially, for low income families) has not been fully resolved in both developed and developing countries from past to present [14]. In countries such as Turkey where housing is seen as a guarantee, demand for investment by high income group is very important. In this case, there may be more than one housing in their ownership, except for the house that the individual uses. The majority of these dwellings are offered on the market as rental housing stocks. For middle and lower income groups, purchasing a house is still an important problem. Especially, housing supply for lower income group is a serious problem and policies for purchasing house of lower income group are still insufficient. In this sense, housing loan system is not yet able to run for its purpose. The main reason for this failure is that the interest rates on housing loans are still quite high in today's conditions [15]. Turkey real estate sector is a significant driving force in its economy due to employment along with many subsectors such as tourism and building. To choose a suitable location for investors who want to purchase a house has become a crucial matter since price and demand as well as gross domestic product per capita are increasing. Site selection literature $[2-5,16-18]$, opinions of housing development and valuation experts, and a Ph.D. Thesis [19] were used for selection of criteria and, finally, 29 criteria with evaluations of authors were determined. Our study focuses on selection problem of best suitable among existing ones for sale with the help of housing suitability evaluation whenever a customer wants to buy a house depending on 29 criteria which are related to distance, building, and surrounding properties among others. To solve this problem MCDM and Evolutionary Algorithm (EA) approaches can be considered with weighting of criteria to either single or multiple sets of objectives [20]. However, these methods used alone reveal serious deficiencies from the view of geographical aspects [21] and are eliminated to a large extent with Spatial Decision Support System (SDSS) technique considering heterogeneity in environment [22]. Many studies have used the MCDM techniques like ordered weighted averaging (OWA) [23], analytical hierarchy/network [24] process, ELECTRE (elimination and choice expressing reality) [25], PROMETHEE (the preference ranking organization method for enrichment of evaluations) [26], EA [27], Combined Decision Making Trial and Evaluation Laboratory (DEMATEL), the Analytic

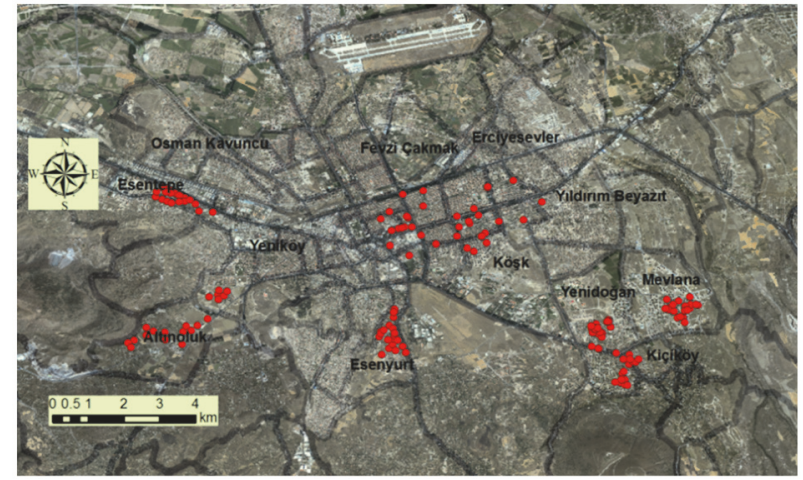

FIGURE 1: Housing locations on the satellite map of Kayseri.

Network Process (ANP) and Multiattributive Border Approximation area Comparison (MABAC) [16], and Multiattributive Ideal-Real Comparative Analysis (MAIRCA) [17]. SDSS has been carried out by using Geographic Information System (GIS) together with MCDM and EA techniques [28]. This approach reduces deficiencies in combination of geographical features of subjective values and preferences [29]. GIS as an ideal tool to analyze and solve multicriteria problems can easily update the existing information upon the availability of new or better information [30,31]. Researchers working on SDSS to solve site selection problems have been investigating various methods to integrate MCDM or/and EA techniques into GIS [16-18, 20, 32, 33]. Location or site selection problem which involves the evaluation of multiple criteria is still one of the significant decision parameters for decision makers. More recently, we have faced a few studies in the literature about combined GIS and EA solving site selection problems [34-37]. The main objective of our study was to produce a suitability map through the combination of MCDM and GIS by assessing suitability of housing location. At the end of the study, we obtained the map having the highest housing suitability evaluation value with combined CMA-ES-WLC approach by comparing an objective (mathematical) and a subjective method.

\section{Materials and Methods}

As a result of field work conducted in Kayseri city of Turkey, dwellings used in this study were specified on the basis of housing for sale. Criteria employed were determined by the study on real estate development. Locations of the houses were taken from Google Earth (Figure 1). Target population of the study is approximately 2000 residential units sold in Kayseri during the last one month. In order to gather information about housing criteria shown in Table 1, a questionnaire was done with customers. The sample size data found pertaining to 160 dwellings was collected from different districts of Kayseri. Housing site selection is the most critical strategic decision a customer has to make. Because of the significance of site location in the quality of life, customers carefully evaluate many variables and competitive housing sites before selecting. 


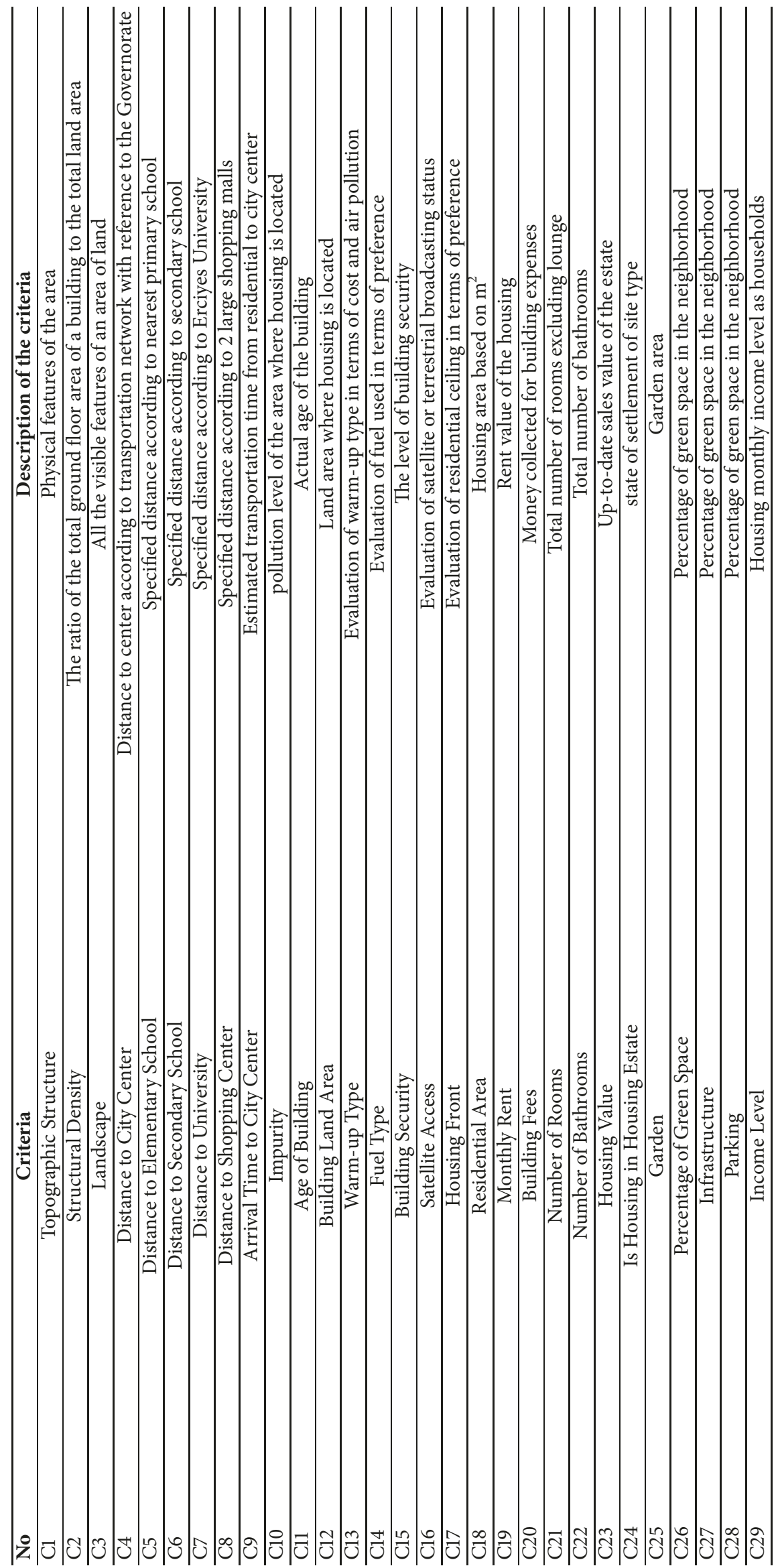




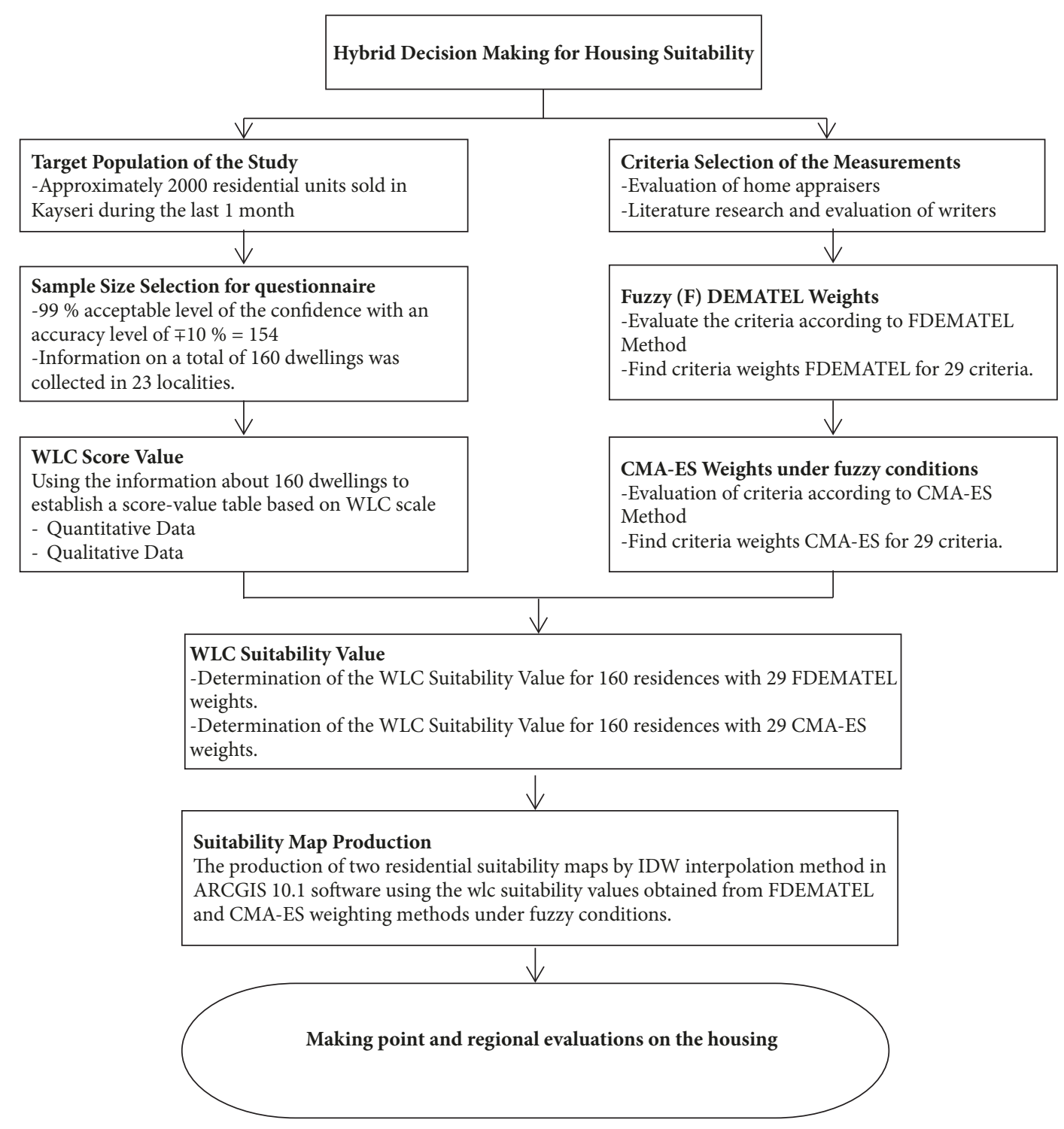

FIgURE 2: Hybrid decision making for housing suitability flow diagram.

In order to better understand the material and the methodology used, housing suitability flow diagram employed in the study is given in Figure 2.

\subsection{Weights of Criteria Estimation}

2.1.1. CMA-ES Algorithm and Optimization. As an evolutionary approach to solve housing location site selection problem, we considered CMA-ES algorithm under fuzzy conditions necessary. Since EAs for local and global optimization solutions are fast and robust computation methods, they have been widely used as a state of the art method. CMA-ES as a class of continuous EAs was proposed by Hansen [38]. In particular, CMA-ES which is one of the most effective EAs due to its self-training behaviour is often preferred to other ES (Evolutionary Strategy) techniques for continuous objective functions [39]. Compared to other EAs, invariability against the linear transformations in the search space is an important characteristic of CMA-ES which is a stochastic method generating new population member by sampling from a probability distribution that is constructed during the optimization process. Training process of correlations between parameters and use of the correlations to accelerate convergence of the algorithm are key concepts of this algorithm. In recent years, there have been many studies about CMA-ES or hybrid CMA-ES approach. These studies in the literature proved that CMA-ES is a more efficient EA than others in improving performance of systems [40]. CMA-ES is one of the most efficient metaheuristics for dealing with difficult numerical optimization problems [41]. Another reason to prefer such algorithm is that a modification of the constraints may not require a reformulation of the problem, which, in practice, may be of considerable usefulness [42]. This choice may thus also have some operational advantages. CMA-ES are generally the most effective strategies on nonseparable and badly scaled problems and advantages, showing in particular 


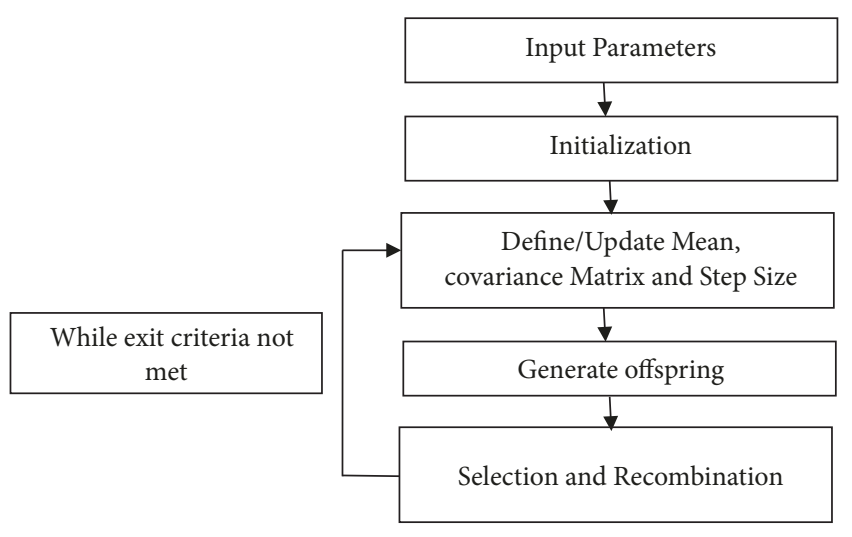

Figure 3: A cycle of stages for CMA-ES works.

active decrease in the sampling variance [43, 44]. CMAES, which performs for nonlinear function minimization, produces a Gaussian probabilistic model of finding solutions and the next generation population and works through a cycle of stages represented in Figure 3.

In our study as a new hybrid approach, we used CMAES-WLC as an objective (mathematical model) approach to be able to obtain the most suitable solution to draw the map based on GIS and compared Fuzzy DEMATELWLC as a subjective method. If we use fuzzy approach in decision making, it presents powerful reasoning that can handle uncertainties and vagueness. Therefore, we use CMAES under fuzzy conditions to find the importance weight of each criteria wi. With $\mathrm{n}$ criteria, let $w=\left(w_{1}, w_{2}, \ldots, w_{n}\right.$ ) be priority vector of criteria $\left(0<w_{i}<1\right)$ and $E W_{i j}=\left(x l_{i j}\right.$, $\left.x m_{i j}, x u_{i j}\right)$ present the importance of criteria ci respective to criteria $c j$ in pairwise comparison by decision maker $(i<j)$. Finding the value of weight $w_{i}$ is similar to the value of ratio $w_{i} / w_{j}$, which maximizes their membership function in the corresponding fuzzy set $E W_{i j}$. Triangular fuzzy membership function $\mu_{i j}$ is defined in (1).

$$
\mu_{i j}\left(\frac{w_{i}}{w_{j}}\right)= \begin{cases}\frac{w_{i} / w_{j}-x_{i j}^{l}}{x_{i j}^{m}-x_{i j}^{u}} & x_{i j}^{l} \leq \frac{w_{i}}{w_{j}} \leq x_{i j}^{m} \\ \frac{w_{i} / w_{j}-x_{i j}^{u}}{x_{i j}^{m}-x_{i j}^{u}} & x_{i j}^{l} \leq \frac{w_{i}}{w_{j}} \leq x_{i j}^{u} \\ 0 & \text { otherwise }\end{cases}
$$

A fitness function was proposed by Moneim, [45] as defined in (2).

$$
G\left(w_{1}, w_{2}, \ldots, w_{n}\right)=\min _{i<j}\left(\mu_{12}, \mu_{13}, \ldots \mu_{i j}, \ldots, \mu_{(n-1) n}\right)
$$

The problem of obtaining a priority vector of $\mathrm{n}$ criteria can be determined in the following optimization problem defined in (3).

$$
\begin{aligned}
\text { Maximize } & G\left(w_{1}, w_{2}, \ldots, w_{n}\right) \\
\text { Subject to } & \sum_{i=1}^{n} w_{i}=1 \\
\text { Where } & G\left(w_{1}, w_{2}, \ldots, w_{n}\right)
\end{aligned}
$$

In our study, CMA-ES under fuzzy conditions was used to make clear the optimization problem formulated in (3). The quality of a solution is defined by the fitness function. The problem was coded and solved by MATLAB 2011 in 2016. Elapsed time for solution and the number of iteration were 188.86 seconds and 197218, respectively. CMA-ES algorithm has been explained by many sources in detail $[38,46]$. Besides, the steps of algorithm are given in the Supplementary Materials (available here).

2.1.2. Fuzzy DEMATEL (FDEMATEL). FDEMATEL was used first by Lin and $\mathrm{Wu}$ [47] while DEMATEL was developed by Gabus and Fontela [48]. It is helpful for monitoring the structure of complex causal relationships with matrices or digraphs. FDEMATEL is a method which gathers group ideas and analyzes the cause and effect relationship of complicated problems in fuzzy environments. Shieh et al. [49] evaluated the importance of the criteria and constructed the causal relationships among the criteria with FDEMATEL. Converting Fuzzy Data into Crisp Scores (CFCS) defuzzification method generated by Opricovic and Tzeng [50] was employed in this paper. Since Fuzzy DEMATEL method can get an intelligible structural model of the system by transforming the relationship between the causes and effects of criteria [5153], this method has been chosen for weighing the criteria [54]. The procedure for weighing criteria of the FDEMATEL method is shortly explained below [55] and given in the Supplementary Materials as detailed.

Step 1. Identify the decision aim and establish a committee.

Step 2. Develop the assessment criteria and design the fuzzy linguistic range.

Step 3. Acquire and average the evaluations of decision makers.

Step 4. Steps of Converting Fuzzy data into Crisp Scores defuzzification Method

Step 5. Acquire the normalized direct-relation fuzzy matrix. $(\widetilde{X})$

Step 6. Acquire the total-relational fuzzy matrix $(\widetilde{T})$

Step 7. Determine the criteria weights. $\left(\omega_{i}\right)$

2.2. Combination of MCDM and WLC. Our problem is to find the best one among the existing housing for the customer who wants to purchase a house. Generally, MCDM techniques are required to answer this problem. This study combines the spatial analyst of GIS and multicriteria decision analysis in the housing evaluation site selection model. The choice of weights and weighting techniques has an important effect on decision making. In MCDM methods, the most important point is to find criteria weights especially objective. While criteria weights determined with subjective decision making methods depend on decision makers' preferences, weights with objective decision making are obtained from 
mathematical models [56]. Weights assigned to criteria in MCDM methods are the most important task and step to reach final results mostly depending on such weights. Writers working on MCDM have more commonly indicated that there is no single MCDM method considered which can be superior method for all decision making problems to weigh the criteria [57-59]. Recently, some authors have used some performance evaluation approach to make criteria weights correct and overcome this problem [60]. In this study, performance measurement for alternative ranking was performed by maximizing WLC that is probably the most used MCDM technique in land suitability score calculations related to GIS. The higher WLC score, the more suitable site selection area. The total WLC score for each alternative is calculated by multiplying the weight assigned to each attribute by the scaled value and then summing the products over all attributes. The sum of weights as a requirement in producing the final susceptibility map must equal 1 . Different data layers for 29 criteria which correlate to various physical, cultural, or economic factors that would be important for site selection analysis were created and mapped [2-5, 9]. The results are often shown on a map that is employed to highlight areas from high to low suitability [20,21]. With the help of WLC, factors are put together by applying a weight to each factor followed by a summation of the results to acquire a suitability map. In our study, proposed housing areas were selected by assigning weights based on the criteria determined by real estate agencies and literature search [19]. Suitability index (S) to generate the overall score of a cell is given in the following formula defined in

$$
S=\sum_{i=1}^{n} W_{i} \cdot X_{i} \prod_{j=1}^{m} C_{j}
$$

where $S$ is the suitability, $W_{i}$ the weight of factor $i, n$ the number of factors, $X_{i}$ the criterion score of factor $i$ in continued range, and $C_{j}$ restricted state for any area. WLC function of ArcGIS model builder has been applied to generate housing evaluation suitability map. Malczewski and Rinner [61] highlighted WLC as the most popular MCE (Multicriteria Evaluation) method about suitability analysis with GIS on location which was developed by Voogd [62]. In order to find the suitable alternatives for housing site selection, WLC models have been commonly used in SDSS. Generally, SDSS considers many criteria to make a decision. Since determining the factor weights of WLC effectively and in a realistic style without user bias is difficult as a weakness point, different MCDM methods have been used to find the weights of criteria with the combination of WLC. The outcomes exhibited the capability of the model to eliminate human interference. Suitability score indicates which locations or areas are particularly well suited for a specific purpose. A suitability map is created as a result of obtaining the suitability score. The evaluation was done by intersecting 29 criteria such as social, economic, ecologic, and environmental as given in Table 1. We assumed that suitability is linear with respect to scores and that variables are independent. Organizing a single index of evaluation combined by MCDA provides information about several criteria. To combine continuous factors by applying a weight to each factor, a linear combination is used to get a suitability map $[63,64]$. One of the significant applications for spatial planning and management is GIS-based land suitability mapping [65]. Score values in decision matrix are standardized as defined in

$$
v\left(a_{i k}^{q}\right)= \begin{cases}\frac{a_{i k}^{q}-\min _{i, q}\left\{a_{i k}^{q}\right\}}{r_{k}^{q}}, & \text { for the } k-t h \text { criterion to be maximized } \\ \frac{\max _{i, q}\left\{a_{i k}^{q}\right\}-a_{i k}^{q}}{r_{k}^{q}}, & \text { for the } k-t h \text { criterion to be minimized }\end{cases}
$$

where $\min \left\{a_{i k}\right\}$ and $\max \left\{a_{i k}\right\}$ are the values of minimum and maximum criterion for the $\mathrm{k}$-th criterion, respectively, and $r_{k}=\max \left\{a_{i k}\right\}-\min \left\{a_{i k}\right\}$ is the global range of the kth criterion. In the standardized score values $v\left\{a_{i k}\right\}$, ranging from 0 to 1,0 is the least suitable value while 1 is the most desired score.

\section{Results}

According to the linguistic variables in Table 2, real estate experts and decision makers selected randomly from houses evaluated decision criteria. The data were obtained from housing based different locations.

To determine the weighting of criteria is a significant point in MCDM. Many researchers have accepted direct and indirect way for deciding the value of criteria weighting.
Decision maker's preference or opinion may contain uncertain information. Thus, methods might result in some inconsistency in the weighting. The purpose of the comparison for the MCDA methods is to demonstrate the feasibility of the model-based objective approaches and which MCDA methods will be more suitable in selection and evaluation problems. In this study, ten real estate experts working in the market were asked for the evaluation of 29 decision criteria. The results calculated using FDEMATEL and CMA-ES under fuzzy conditions were given in Table 3 . The criteria weights obtained from CMA-ES and the FDEMATEL algorithms were processed manually in ArcGIS using WLC method.

Figure 4 shows a sample grid-cells suitability value calculation for 29 criteria for the effect of scale on WLC suitability value. The weights were obtained from the CMA-ES method. Equation (5) has been used for the score values. Score values 
TABLE 2: Linguistic scales for criteria weights and alternatives.

\begin{tabular}{lccc}
\hline Linguistic variables Fuzzy (FDEMATEL) & Triangular fuzzy number & Linguistic variable (CMA-ES) & Triangular Fuzzy Number \\
\hline No Impact $(\mathrm{N})$ & $(0.00,0.00,0.25)$ & Equally strong & $(1,1,1)$ \\
Very Low Impact (VL) & $(0.00,0.25,0.50)$ & Intermediate & $(1,2,3)$ \\
Low Impact (L) & $(0.25,0.50,0.75)$ & Moderately strong & $(2,3,4)$ \\
High Impact (H) & $(0.50,0.75,1.00)$ & Intermediate & $(3,4,5)$ \\
Very High Impact (VH) & $(0.75,1.00,1.00)$ & Strong & $(4,5,6)$ \\
& & Intermediate & $(5,6,7)$ \\
& & Very strong & $(6,7,8)$ \\
& & Intermediate & $(7,8,9)$ \\
\end{tabular}

Housing Value (1000TL)

\begin{tabular}{|c|c|c|c|c|c|c|c|c|}
\hline 110 & 130 & 80 & 120 & & 0,25 & 0,42 & 0,00 & 0,33 \\
\hline 100 & 120 & 90 & 195 & (Standardize) & 0,17 & 0,33 & 0,08 & 0,96 \\
\hline 120 & 160 & 90 & 200 & & 0,33 & 0,67 & 0,08 & 1,00 \\
\hline 95 & 100 & 87 & 125 & & 0,13 & 0,17 & 0,06 & 0,38 \\
\hline
\end{tabular}

Landscape Score

\begin{tabular}{|c|c|c|c|c|c|c|c|c|}
\hline 110 & 130 & 80 & 120 & & 0,00 & 0,67 & 0,67 & 0,67 \\
\hline 100 & 120 & 90 & 195 & (Standardize) & 0,67 & 0,00 & 0,67 & 0,67 \\
\hline 120 & 160 & 90 & 200 & & 1,00 & 0,00 & 0,67 & 0,37 \\
\hline 95 & 100 & 87 & 125 & & 1,00 & 0,67 & 0,37 & 1,00 \\
\hline
\end{tabular}

\begin{tabular}{|c|c|c|c|c|c|c|c|c|}
\hline$\ldots$ & $\ldots$ & $\cdots$ & $\ldots$ & & $\ldots$ & $\ldots$ & $\ldots$ & $\ldots$ \\
\hline$\ldots$ & $\ldots$ & $\cdots$ & $\ldots$ & (Standardize) & $\ldots$ & $\ldots$ & $\ldots$ & $\ldots$ \\
\hline$\ldots$ & $\ldots$ & $\ldots$ & $\ldots$ & & $\ldots$ & $\ldots$ & $\ldots$ & $\ldots$ \\
\hline$\ldots$ & $\ldots$ & $\ldots$ & $\ldots$ & & $\ldots$ & $\ldots$ & $\ldots$ & $\ldots$ \\
\hline
\end{tabular}

\begin{tabular}{|l|l|l|l|}
\hline 0,81 & 0,81 & 0,23 & 0,85 \\
\hline 0,79 & 0,77 & 0,19 & 0,92 \\
\hline 0,22 & 0,83 & 0,84 & $\mathbf{0 , 9 3 *}$ \\
\hline 0,23 & 0,17 & 0,75 & 0,81 \\
\hline
\end{tabular}

Parking

\begin{tabular}{|c|c|c|c|c|c|c|c|c|}
\hline 4 & 3 & 4 & 4 & & 1,00 & 0,00 & 1,00 & 1,00 \\
\hline 4 & 4 & 3 & 4 & (Standardize) & 1,00 & 1,00 & 0,00 & 1,00 \\
\hline 4 & 4 & 4 & 4 & & 1,00 & 1,00 & 1,00 & 1,00 \\
\hline 4 & 3 & 4 & 4 & & 1,00 & 0,00 & 1,00 & 1,00 \\
\hline
\end{tabular}

$*$ Best Cell

FIGURE 4: The effect of scale on WLC suitability value.

were obtained from the questionnaire data relying on 160 houses as a sample.

A location of houses and information based on criteria was determined with positional database logic using on ArcGIS raster map. The 3 most commonly used interpolation methods in the ArcGIS program have been investigated by comparing RMSE values. These values were mapped as vectorial (positional) and transformed to raster (pixel) data using IDW (Inverse Distance Weighting) interpolation as a deterministic spatial interpolation model adopted by geoscientists to find the unknown location method. In order to predict the unknown interval values, the points close to each other were clustered together. According to the IDW method, the highest weight is assigned to the nearest one where the 


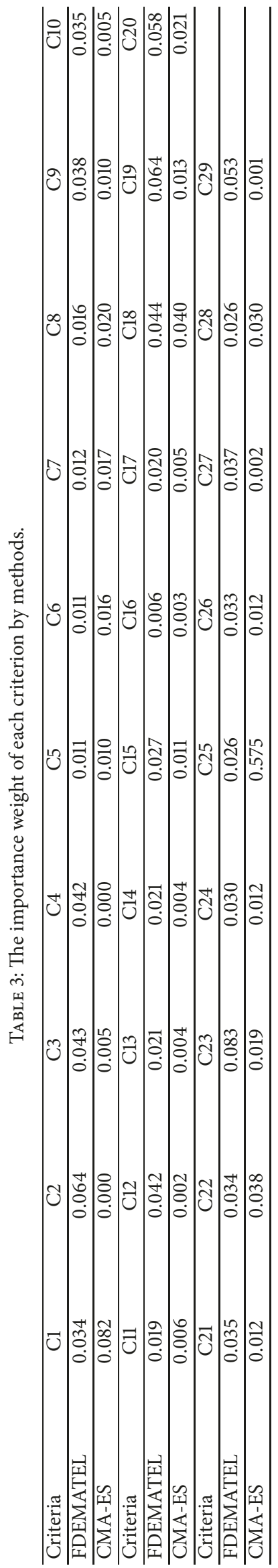




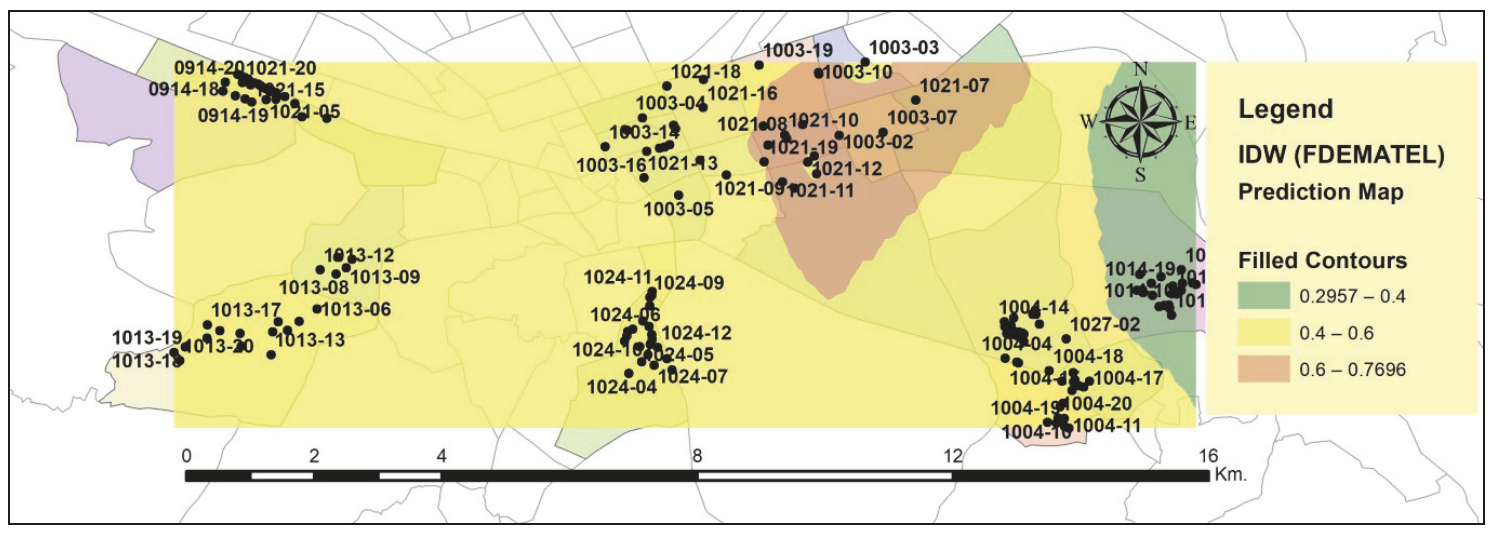

FIGURE 5: Areal raster map obtained from FDEMATEL weights and WLC suitability values.

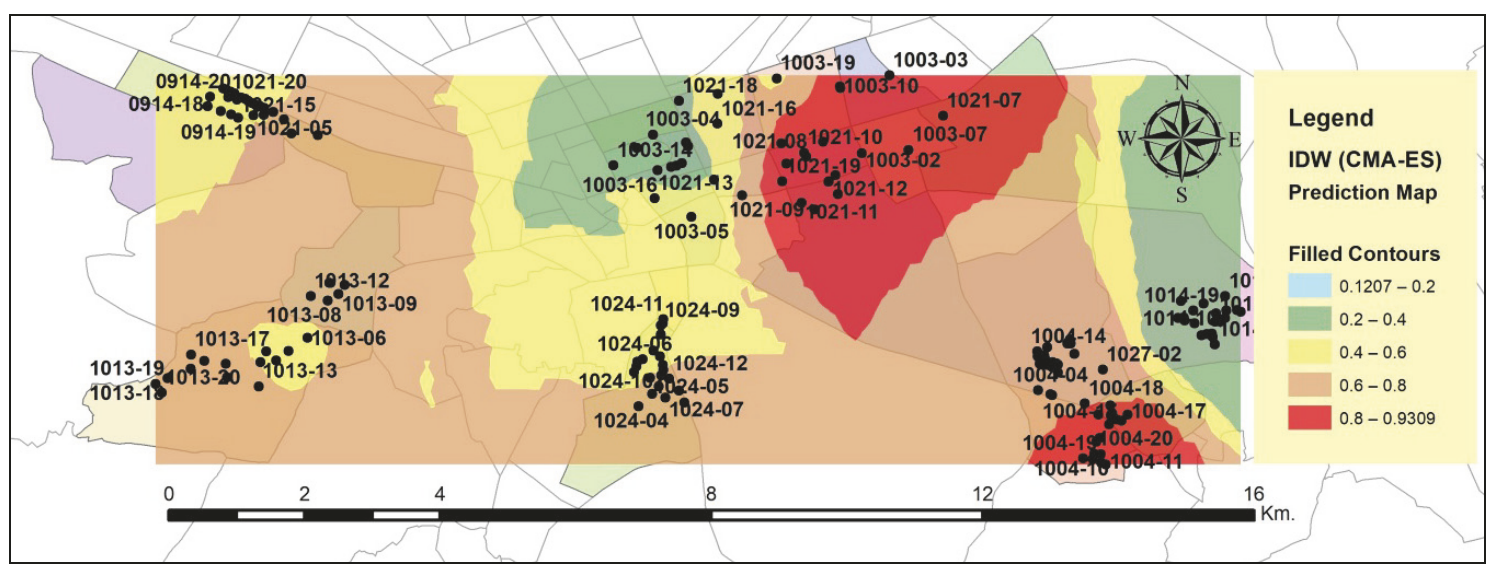

FIGURE 6: Areal raster map obtained from CMA-ES weights and WLC suitability.

smallest weight value is assigned to the farthest one. As a result, IDW interpolation method was chosen because IDW RMSE: 0.2501, RBF RMSE: 0.2536, and Ordinary Kriging RMSE: 0.2725 were obtained. Two different raster maps were produced by applying the IDW interpolation method based on WLC suitability values obtained from the residential basis. The WLC classification was made to be very low suitability from 0 to 0.20 , low suitability from 0.20 to 0.40 , moderate suitability from 0.4 to 0.60 , high suitability from 0.60 to 0.80 , and very high suitability from 0.80 to 1 . Raster map obtained from CMA-ES weights was divided into 5 classes but that produced by FDEMATEL weights was divided into 3 classes for WLC suitability values (Figures 5 and 6).

When comparing between Figures 4 and 5, areas with very high suitability on the map obtained from CMA-ES weights seems to be similar to the high suitability areas obtained by FDEMATEL weights. The low suitability area in the northeast of CMA-ES weights and the low suitability area of FDEMATEL weights were identical. The map obtained from FDEMATEL weights has not shown very high and very low suitability areas. It seems to be a medium-suitability (yellow) area in large proportion. Accordingly, the suitability map obtained from CMA-ES weights has shown all classes and produced more sensitive map.

In this context, the WLC was employed in the criteria aggregation, producing a priority map for Kayseri that was classified into five priority levels: very low, low, medium, high, and very high. It seems clear that these weights will have full effect with WLC operator. The suitability status of all the dwelling units assessed for the WLC values calculated with CMA-ES and FDEMATEL weights is shown on the Kayseri neighbourhood map (Figure 7). According to this map, it has been seen that the houses with the highest suitability in terms of investment are in Alpaslan, Köşk, and Melikgazi streets. This shows that the suitability maps obtained with the weights in these areas and the housing values are compatible with each other.

Our goal from a performance criterion measuring the weighting efficiency is to maximize the WLC value for 160 alternatives. We achieved CMA-ES-WLC maximization values for 104 alternatives but we obtained FDEMATEL-WLC maximization values for 56 alternatives as shown in Table 4 . Thus, housing suitability map was performed with CMA-ES weighting model approach. Since the WLC value close to 1 is 


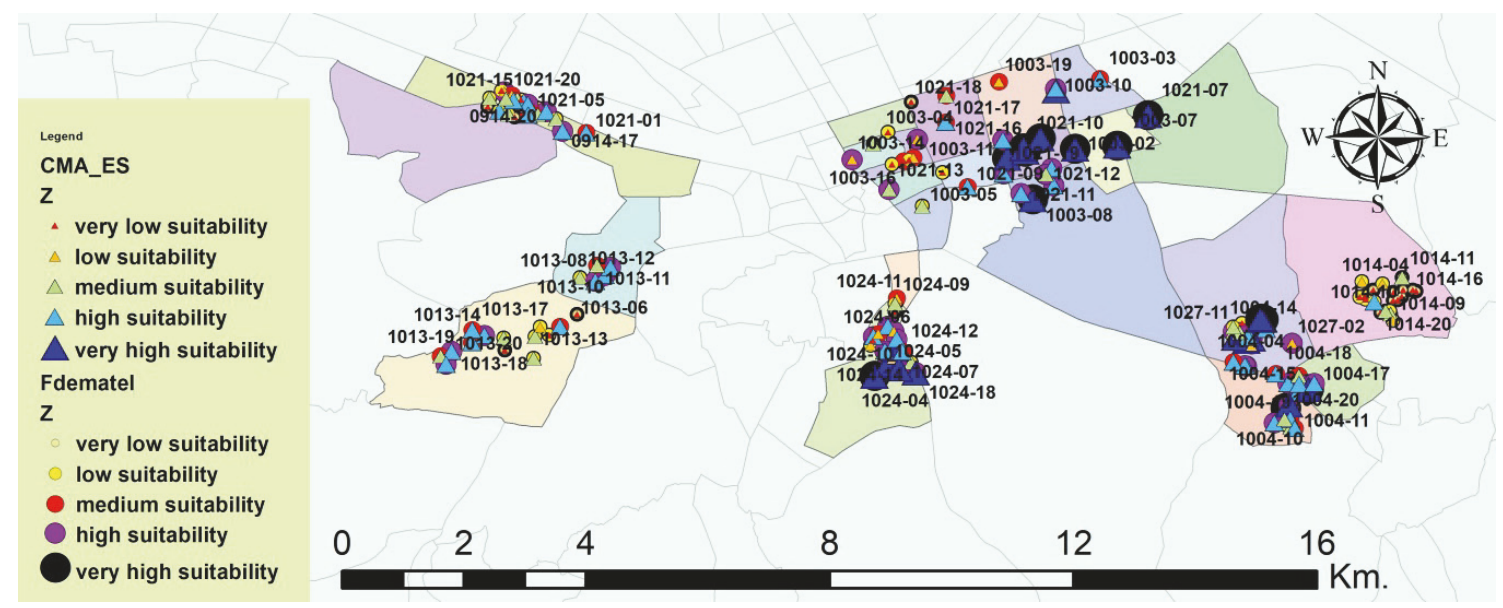

FIGURE 7: Housing location suitability comparison by hybrid weighting definition methods.

TABLE 4: Differences between CMA-ES and FDEMATEL models.

\begin{tabular}{lccc}
\hline Name & WLC Suitability Value for CMA-ES & WLC Suitability Value for FDEMATEL & Difference \\
\hline $1014-08$ & 0.25 & 0.42 & -0.17 \\
$1014-07$ & 0.18 & 0.37 & -0.19 \\
$1014-06$ & 0.21 & 0.41 & -0.20 \\
$1014-05$ & 0.21 & 0.39 & -0.18 \\
$\ldots$ & $\ldots$ & 0.44 & $\ldots$ \\
$1024-09$ & 0.77 & 0.51 & 0.33 \\
$1024-12$ & 0.83 & 0.53 & 0.32 \\
$1003-14$ & 0.23 & 0.52 & -0.30 \\
$1003-19$ & 0.27 & & -0.25 \\
\hline FDEMATEL performance (negative value) & & & $56(35 \%)$ \\
\hline CMA-ES performance (Positive value) & & & $104(65 \%)$ \\
\hline
\end{tabular}

the most suitable value, if the difference is positive, it is the reason for preference.

\section{Discussion and Conclusions}

This paper has shown that evolutionary-based map production in the evaluation of housing as an objective approach is likely more efficient than subjective approaches. We propose CMA-ES-WLC as a new hybrid EA for the solution of site selection problem with respect to performance evaluation based on suitability value. In order to produce housing suitability raster map, WLC approach was applied successfully by measuring performance of criteria weights. Successful implementation of this study would enable decision makers to follow a comprehensive easy-to-use procedure to make the correct decision. The criterion number 25 described as garden is the most important factor for CMA-ES in maximizing the decision goal. Therefore, today and in the future, decision maker should firstly take this factor into consideration in urban planning because of priority preference of customers. IDW interpolation method was employed to determine appropriate region in the mapping. The problem of optimizing housing and regional selection was solved in terms of individual and institutional investment. By setting their own criteria on these maps in accordance with their own goals, anybody can determine the most suitable housing or the area where their residence is located. Local governments will be able to adjust their services accordingly by determining which criteria are the most important. Local taxation coefficients can be obtained to increase wealth by making classifications on the map developed by the local governments in determining property taxes as a result of this study. Development of a regional housing evaluation map will help determine service quality standards in fulfilling responsibilities of central and local governments. Governments will be able to distribute services provided by local authorities on an equal basis across their city. Aforementioned features are useful for a municipal agency to do a housing evaluation map for planning purposes. In Table 5, we found some classification dimension from the results obtained and some interpretation can be made about housing location areas (zones) as follows:

S1: When WLC classification is made according to both weight methods, there is no worst zone in terms of housing evaluation and selection.

S2: According to both weighting methods in terms of housing evaluation and selection, a region of about $10 \%$ is worse based on WLC classification. In the classification map obtained from the FDEMATEL method, only the marginal 
TABLE 5: Classification dimension of suitability zones for CMA-ES and FDEMATEL models.

\begin{tabular}{|c|c|c|c|c|c|}
\hline \multirow{2}{*}{ Suitability Zones } & \multirow{2}{*}{ Class } & \multicolumn{2}{|c|}{ Percent (\%) } & \multicolumn{2}{|c|}{ Area $\left(\mathrm{km}^{2}\right)$} \\
\hline & & FDEMATEL & CMA-ES & FDEMATEL & CMA-ES \\
\hline S1 (0.0000-0.1999) & Very Low Suitability & 0 & 0 & 0.00 & 0.00 \\
\hline S2 (0.2000-0.3999) & Low Suitability & 8 & 13 & 6.51 & 10.58 \\
\hline S3 (0.4000-0.5999) & Medium Suitability & 81 & 22 & 65.94 & 17.91 \\
\hline S4 (0.6000-0.7999) & High Suitability & 11 & 51 & 8.95 & 41.51 \\
\hline S5 (0.8000-1.0000) & Very High Suitability & 0 & 14 & 0.00 & 11.40 \\
\hline Total & & 100 & 100 & 81.40 & 81.40 \\
\hline
\end{tabular}

areas which are east of Kayseri were found as poor regions. According to the CMA-ES method, some of the old streets in the city and the streets in the east of the city were identified as poor districts. They are the areas where people who have a low income level live and which are generally unplanned.

S3: According to FDEMATEL weights and WLC classification, $80 \%$ of the residential areas fall into this area. In the CMA-ES weights and WLC classification, $22 \%$ of the residential areas are located in this region. Even though these areas are planned, they are now developing regions according to the plan of the city of 30-40 years ago and where the people belonging to low-middle-income level live.

S4: These regions are good areas for housing quality and planned settlements. Generally, the income levels are in the regions where people live on average of about \$1000 a month. According to the CMA-ES weighting method, 51\% of the entire area is available as a suitable region. This situation is consistent with Turkey's economic realities and Kayseri.

S5: This region did not occur in the FDEMATEL method and the WLC classification. According to the CMA-ES method and WLC classification, the most suitable areas include Kayseri's most prestigious streets such as Alpaslan, Köşk, Melikgazi, and Gültepe. They are the most beautiful regions of the city in terms of planning and have shown great development since 2000's. Housing values are also high in the region. They are close to Sivas street and tram line which provide main transportation of the city. The income level of people living in this region is about 2000 dollars a month.

Nowadays, the development of web-based data collection systems is necessary to apply for all countries since they will bring a new perspective in the evaluation and selection of housing. Raster maps can be drawn in the future by calculating web-based suitability values. In the future study, different evolutionary/hybrid evolutionary algorithms (such as RAND: a random search algorithm, FFGA: Fonseca and Fleming's multiobjective EA, NPGA: the Niched Pareto Genetic Algorithm, HLGA: Hajela and Lin's weightedsum based approach, VEGA: the Vector Evaluated Genetic Algorithm, NSGA: the Nondominated Sorting Genetic Algorithm, SOEA: a single-objective evolutionary algorithm using weighted-sum aggregation, and SPEA: the Strength Pareto Evolutionary Algorithm) can be used for housing evaluation [66-73]. With the help of this approach, producers and consumers can invest by specifying their streets or residence by entering their own benchmark values.

\section{Data Availability}

The data used to support the findings of this study are available from the corresponding author upon request.

\section{Conflicts of Interest}

The authors declare that they have no conflicts of interest.

\section{Acknowledgments}

The authors want to express their thanks to Prof. Dr. Franz ROTHLAUF from the Department of Information Systems, Mainz University, Germany, for his invaluable and significant contributions and Dr. Burak URAZEL from the Department of Electrical and Electronics Engineering, Osmangazi University, Turkey, because of his help in coding which was required.

\section{Supplementary Materials}

This section is used for finding the weighting of criteria (factors) by application of Fuzzy DEMATEL and CMA-ES Method. (Supplementary Materials)

\section{References}

[1] J. Tosun, "How the eu handles uncertain risks: understanding the role of the precautionary principle," Journal of European Public Policy, vol. 20, no. 10, pp. 1517-1528, 2013.

[2] A. L. Dannenberg, R. J. Jackson, H. Frumkin et al., “The Impact of Community Design and Land-Use Choices on Public Health: A Scientific Research Agenda," American Journal of Public Health, vol. 93, no. 9, pp. 1500-1508, 2003.

[3] H. Barton, "Land use planning and health and well-being," Land Use Policy, vol. 26, no. 1, pp. S115-S123, 2009.

[4] F. Dieleman, Households and housing: Choice and outcomes in the housing market, Routledge, 2017.

[5] J. Dumanski, "Criteria and indicators for land quality and sustainable land management," ITC Journal, vol. 1997, no. 3-4, pp. 216-222, 1997.

[6] Land Use Planing, 2017, http://www.sustainablecitiesinstitute.org/ topics/land-use-and-planning/land-use-and-planning-traditional-approaches.

[7] M. Kasanko, J. I. Barredo, C. Lavalle et al., "Are European cities becoming dispersed? A comparative analysis of 15 European 
urban areas," Landscape and Urban Planning, vol. 77, no. 1-2, pp. 111-130, 2006.

[8] Land Use 2017, 2017, http://www.sustainablecitiesinstitute.org/ Documents/SCI/Topic_Overviews/Land\%20Use\%20-\%20Full\% 20OverviewNew_NLC.pdf.

[9] J. Malczewski, "GIS-based land-use suitability analysis: a critical overview," Progress in Planning, vol. 62, no. 1, pp. 3-65, 2004.

[10] "Law On Land Development Planning And Control, Law No: 3194, Date of Enactment: 3/5/1985, Published in the Official Gazette: Date: 9/5/1985 Issue: 18749, Publication Series," vol. 5, no 24, pp. 378, 1985.

[11] A. Öcü, "The politics of the urban land market in Turkey: 19501980," International Journal of Urban and Regional Research, vol. 12, no. 1, pp. 38-64, 1988.

[12] J. Corburn, Toward the healthy city: people, places, and the politics of urban planning, MIT Press, 2009.

[13] A. Bozdağ, "Combining AHP with GIS for assessment of irrigation water quality in Çumra irrigation district (Konya), Central Anatolia, Turkey," Environmental Earth Sciences, vol. 73, no. 12, pp. 8217-8236, 2015.

[14] A. Ugurlar and T. Ö. Eceral, “Türkiye'de konut politikalarinin gelişim süreci ve Ankara Metropol kentinde mevcut kiralik konut piyasasina ilişkin bir değerlendirme," in Kbam Kentsel ve Bölgesel Araştırmalar A $\breve{g} \mathrm{l}$ 3. Kent Bölgeler, Metropoliten Alanlarve Büyükşehirler, vol. 3, pp. 6-7, Metropoliten Alanlar ve Büyükşehirler, Değişen Dinamikler ve Sorunlar Bildiri Kitabı, Ulusal, 2012.

[15] L. Alkan and A. Uğurlar, "Türkiye'de konut sorunu ve konut politikalari,” Kent Arastirmalari Enstitüsü, Rapor, 2015.

[16] L. Gigović, D. Pamučar, D. Božanić, and S. Ljubojević, "Application of the GIS-DANP-MABAC multi-criteria model for selecting the location of wind farms: A case study of Vojvodina, Serbia," Journal of Renewable Energy, vol. 103, pp. 501-521, 2017.

[17] L. Gigović, D. Pamuĉar, Z. Bajić, and M. Milićević, "The combination of expert judgment and GIS-MAIRCA analysis for the selection of sites for ammunition depots," Sustainability, vol. 8, no. 4, 2016.

[18] D. Pamučar, L. Gigović, Z. Bajić, and M. Janošević, "Location Selection for Wind Farms Using GIS Multi-Criteria Hybrid Model: An Approach Based on Fuzzy and Rough Numbers," Sustainability, vol. 9, no. 8, p. 1315, 2017.

[19] B. Bostanci, Forecasting analysis on real estate development and application of housing area model in Istanbul Unpublished Ph.D. Thesis, Istanbul, 2008, https://tez.yok.gov.tr/UlusalTezMerkezi/.

[20] P. Jankowski, "Integrating geographical information systems and multiple criteria decision-making methods," International Journal of Geographical Information Science, vol. 9, no. 3, pp. 251-273, 1995.

[21] J. Malczewski, "A GIS-based approach to multiple criteria group decision-making," International Journal of Geographical Information Science, vol. 10, no. 8, pp. 955-971, 1996.

[22] M. A. Mohit and M. M. Ali, "Integrating GIS and AHP for land suitability analysis for urban development in a secondary city of Bangladesh," Jurnal Alam Bina, vol. 81, p. 19, 2006.

[23] T. Rashed and J. Weeks, "Assessing vulnerability to earthquake hazards through spatial multicriteria analysis of urban areas," International Journal of Geographical Information Science, vol. 17, no. 6, pp. 547-576, 2003.

[24] X. Ying, G.-M. Zeng, G.-Q. Chen, L. Tang, K.-L. Wang, and D.Y. Huang, "Combining AHP with GIS in synthetic evaluation of eco-environment quality-A case study of Hunan Province, China," Ecological Modelling, vol. 209, no. 2-4, pp. 97-109, 2007.
[25] F. Morari, E. Lugato, and M. Borin, "An integrated nonpoint source model-GIS system for selecting criteria of best management practices in the Po Valley, North Italy," Agriculture, Ecosystems \& Environment, vol. 102, no. 3, pp. 247-262, 2004.

[26] N. J. Martin, B. St Onge, and J.-P. Waaub, "Integrated decision aid system for the development of Saint Charles River alluvial plain, Quebec, Canada," International Journal of Environment and Pollution, vol. 12, no. 2, pp. 264-279, 1999.

[27] M. J. Aitkenhead and I. H. Aalders, "Predicting land cover using GIS, Bayesian and evolutionary algorithm methods," Journal of Environmental Management, vol. 90, no. 1, pp. 236-250, 2009.

[28] J. Malczewski, "GIS-based multicriteria decision analysis: a survey of the literature," International Journal of Geographical Information Science, vol. 20, no. 7, pp. 703-726, 2006.

[29] K. Rajitha, C. K. Mukherjee, and R. Vinu Chandran, "Applications of remote sensing and GIS for sustainable management of shrimp culture in India," Aquacultural Engineering, vol. 36, no. 1, pp. 1-17, 2007.

[30] E. Natividade-Jesus, J. Coutinho-Rodrigues, and C. H. Antunes, "A multicriteria decision support system for housing evaluation," Decision Support Systems, vol. 43, no. 3, pp. 779-790, 2007.

[31] S. J. Carver, "Integrating multi-criteria evaluation with geographical information systems," International Journal of Geographical Information Science, vol. 5, no. 3, pp. 321-339, 1991.

[32] J. Coutinho-Rodrigues, A. Simão, and C. H. Antunes, “A GISbased multicriteria spatial decision support system for planning urban infrastructures," Decision Support Systems, vol. 51, no. 3, pp. 720-726, 2011.

[33] N. Sharmin and M. N. Neema, "A GIS based multicriteria analysis to site appropriate locations of hospitals in Dhaka City," Asian Transactions on Engineering, vol. 03, no. 04, pp. 22214267, 2013.

[34] X. Li and A. G.-O. Yeh, "Integration of genetic algorithms and GIS for optimal location search," International Journal of Geographical Information Science, vol. 19, no. 5, pp. 581-601, 2005.

[35] L. Gigović, D. Pamučar, D. Lukić, and S. Marković, "GISFuzzy DEMATEL MCDA model for the evaluation of the sites for ecotourism development: a case study of 'Dunavski ključ' region, Serbia," Land Use Policy, vol. 58, pp. 348-365, 2016.

[36] G. Romano, P. Dal Sasso, G. Trisorio Liuzzi, and F. Gentile, "Multi-criteria decision analysis for land suitability mapping in a rural area of Southern Italy, Land Use Policy, vol. 48, pp. 131143, 2015.

[37] S. Nasehi, S. Karimi, and H. Jafari, "Application of fuzzy GIS and ANP for wind power plant site selection in east," in Azerbaijan province of Iran, vol. 02, pp. 116-124, Computational Research Progress in Applied Science Engineering, 2016.

[38] N. Hansen, “The CMA Evolution Strategy: A Tutorial Nikolaus," Hansen, 2016, http://cma.gforge.inria.fr/.

[39] S. Y. Yuen, C. K. Chow, X. Zhang, and Y. Lou, "Which algorithm should i choose: An evolutionary algorithm portfolio approach," Applied Soft Computing, vol. 40, pp. 654-673, 2016.

[40] N. Hansen and A. Ostermeier, "Completely derandomized selfadaptation in evolution strategies," Evolutionary Computation, vol. 9, no. 2, pp. 159-195, 2001.

[41] N. Hansen, A. Auger, R. Ros, S. Finck, and P. Pošík, "Comparing results of 31 algorithms from the black-box optimization benchmarking BBOB-2009," in Proceedings of the 12th Annual Genetic and Evolutionary Computation Conference, GECCO-2010, pp. 1689-1696, USA, July 2010. 
[42] S. Belaqziz, S. Mangiarotti, M. Le Page et al., "Irrigation scheduling of a classical gravity network based on the Covariance Matrix Adaptation - Evolutionary Strategy algorithm," Computers and Electronics in Agriculture, vol. 102, pp. 64-72, 2014.

[43] G. A. Jastrebski and D. V. Arnold, "Improving evolution strategies through active covariance matrix adaptation," in Proceedings of the 2006 IEEE Congress on Evolutionary Computation, CEC 2006, pp. 2814-2821, Canada, July 2006.

[44] O. Krause and T. Glasmachers, "A CMA-ES with multiplicative covariance matrix updates," in Proceedings of the 16th Genetic and Evolutionary Computation Conference, GECCO 2015, pp. 281-288, Spain, July 2015.

[45] A. F. A. Moneim, "Fuzzy genetic prioritization in multicriteria decision problems," Jordan Journal of Mechanical and Industrial Engineering, vol. 24, pp. 175-182, 2008.

[46] D. V. Arnold and N. Hansen, "A (1+1)-CMA-ES for constrained optimisation," in Proceedings of the 14th International Conference on Genetic and Evolutionary Computation, GECCO'12, pp. 297-304, USA, July 2012.

[47] C. J. Lin and W. W. Wu, "A causal analytical method for group decision-making under fuzzy environment," Expert Systems with Applications, vol. 34, no. 1, pp. 205-213, 2008.

[48] A. Gabus and E. Fontela, World problems, an invitation to further thought within the framework of DEMATEL, Battelle Geneva Research Center, Geneva, Switzerland, 1972.

[49] J. I. Shieh, H. K. Chen, and H. H. Wu, "Case study of applying fuzzy dematel method to evaluate performance criteria of employment service outreach program," International Journal of Industrial Engineering, vol. 20, pp. 1-20, 2013.

[50] S. Opricovic and G.-H. Tzeng, "Defuzzification within a multicriteria decision model," International Journal of Uncertainty, Fuzziness and Knowledge-Based Systems, vol. 11, no. 5, pp. 635$652,2003$.

[51] C.-Y. Hsu, K.-T. Chen, and G.-H. Tzeng, "FMCDM with fuzzy DEMATEL approach for customers' choice behavior model," International Journal of Fuzzy Systems, vol. 9, no. 4, pp. 236-246, 2007.

[52] Y. Kim, "Study on Impact Mechanism for Beef Cattle Farming and Importance of Evaluating Agricultural Information in Korea Using DEMATEL, PCA and AHP," Agricultural Information Research, vol. 15, no. 3, pp. 267-279, 2006.

[53] A. H. I. Lee, W.-C. Chen, and C.-J. Chang, "A fuzzy AHP and BSC approach for evaluating performance of IT department in the manufacturing industry in Taiwan," Expert Systems with Applications, vol. 34, no. 1, pp. 96-107, 2008.

[54] J. S. Jeong, L. García-Moruno, J. Hernández-Blanco, and A. Sánchez-Ríos, "Planning of rural housings in reservoir areas under (mass) tourism based on a fuzzy DEMATEL-GIS/MCDA hybrid and participatory method for Alange, Spain," Habitat International, vol. 57, pp. 143-153, 2016.

[55] D. Dalalah, M. Hayajneh, and F. Batieha, "A fuzzy multi-criteria decision making model for supplier selection," Expert Systems with Applications, vol. 38, no. 7, pp. 8384-8391, 2011.

[56] A. Aalianvari, H. Katibeh, and M. Sharifzadeh, "Application of fuzzy Delphi AHP method for the estimation and classification of ghomrud tunnel from groundwater flow hazard," Arabian Journal of Geosciences, vol. 5, no. 2, pp. 275-284, 2012.

[57] N. H. Zardari, K. Ahmed, S. M. Shirazi, and Z. B. Yusop, "Literature Review," in Weighting Methods and their Effects on Multi-Criteria Decision Making Model Outcomes in Water
Resources Management, SpringerBriefs in Water Science and Technology, pp. 7-67, Springer International Publishing, Cham, 2015.

[58] M. Velasquez and P. T. Hester, "An analysis of multi-criteria decision making methods," International Journal of Operations Research, vol. 10, no. 2, pp. 56-66, 2013.

[59] E. Triantaphyllou, "Multi-criteria decision making methods," in Multi-criteria Decision Making Methods: A Comparative Study, vol. 44 of Applied Optimization, pp. 5-21, Springer US, Boston, MA, 2000.

[60] B. Bostancı, M. Zeydan, M. Çete, H. Demir, and A. Karaağaç, "Decision Making for Site Selection Using Fuzzy Modeling," Journal of Urban Planning and Development, vol. 143, no. 1, p. 05016010, 2017.

[61] J. Malczewski and C. Rinner, "Multiattribute decision analysis methods," in Multicriteria Decision Analysis in Geographic Information Science, pp. 81-121, Springer, Berlin, Heidelberg, Germany, 2015.

[62] H. Voogd, Multicriteria evaluation for urban and regional planning, vol. 20, London, 1983.

[63] J. Malczewski, "On the use of weighted linear combination method in GIS: Common and best practice approaches," Transactions in GIS, vol. 4, no. 1, pp. 5-22, 2000.

[64] R. J. Eastman, Guide to GIS and Image processing, vol. 2, USA, Clark University, 2001.

[65] J. Malczewski, "Ordered weighted averaging with fuzzy quantifiers: GIS-based multicriteria evaluation for land-use suitability analysis," International Journal of Applied Earth Observation and Geoinformation, vol. 8, no. 4, pp. 270-277, 2006.

[66] C. M. Hosage and M. F. Goodchild, "Discrete space locationallocation solutions from genetic algorithms," Annals of Operations Research, vol. 6, no. 2, pp. 35-46, 1986.

[67] L. Pitaksringkarn and M. A. P. Taylor, "Grouping Genetic Alogirhtm In GIS: A Facility Location Modelling," Journal of the Eastern Asia Society for Transportation Studies, vol. 6, pp. 29082920, 2005.

[68] S. Sasaki, A. J. Comber, H. Suzuki, and C. Brunsdon, "Using genetic algorithms to optimise current and future health planning - the example of ambulance locations," International Journal of Health Geographics, vol. 9, article no. 4, 2010.

[69] D. Gong, M. Gen, G. Yamazaki, and W. Xu, "Hybrid evolutionary method for capacitated location-allocation problem," Computers \& Industrial Engineering, vol. 33, no. 3-4, pp. 577580, 1997.

[70] C. A. C. Coello, G. B. Lamont, and D. A. van Veldhuizen, Evolutionary Algorithms for Solving Multi-Objective Problems, Springer, New York, NY, USA, 2007.

[71] E. Zitzler, K. Deb, and L. Thiele, "Comparison of multiobjective evolutionary algorithms: empirical results," Evolutionary Computation, vol. 8, no. 2, pp. 173-195, 2000.

[72] C. M. Fonseca and P. J. Fleming, "An overview of evolutionary algorithms in multiobjective optimization," Evolutionary Computation, vol. 3, no. 1, pp. 1-16, 1995.

[73] S. Arifin, Location Allocation Problem Using Genetic Algorithm and Simulated Annealing: A Case Study Based on School in Enschede, Unpublished Master's Thesis, Department of Geoinformation Science and Earth Observation, University of Twente, Enschede, The Netherlands, 2011. 


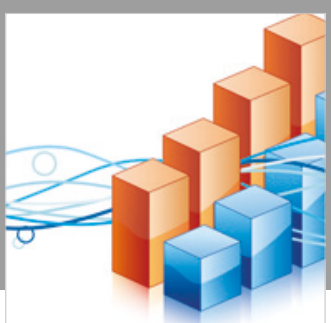

Advances in

Operations Research

\section{-n-m}
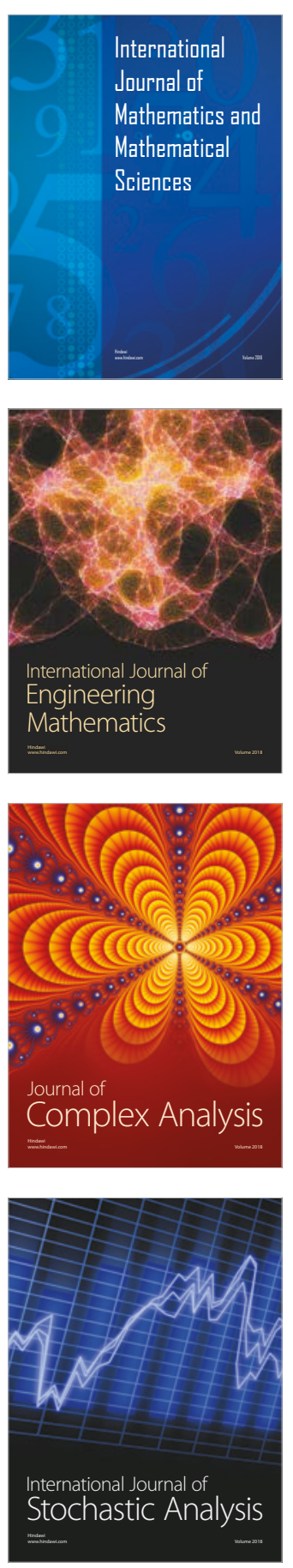
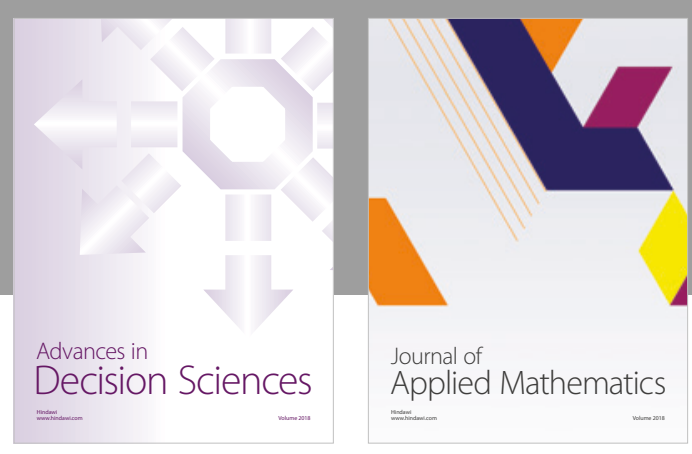

Journal of

Applied Mathematics
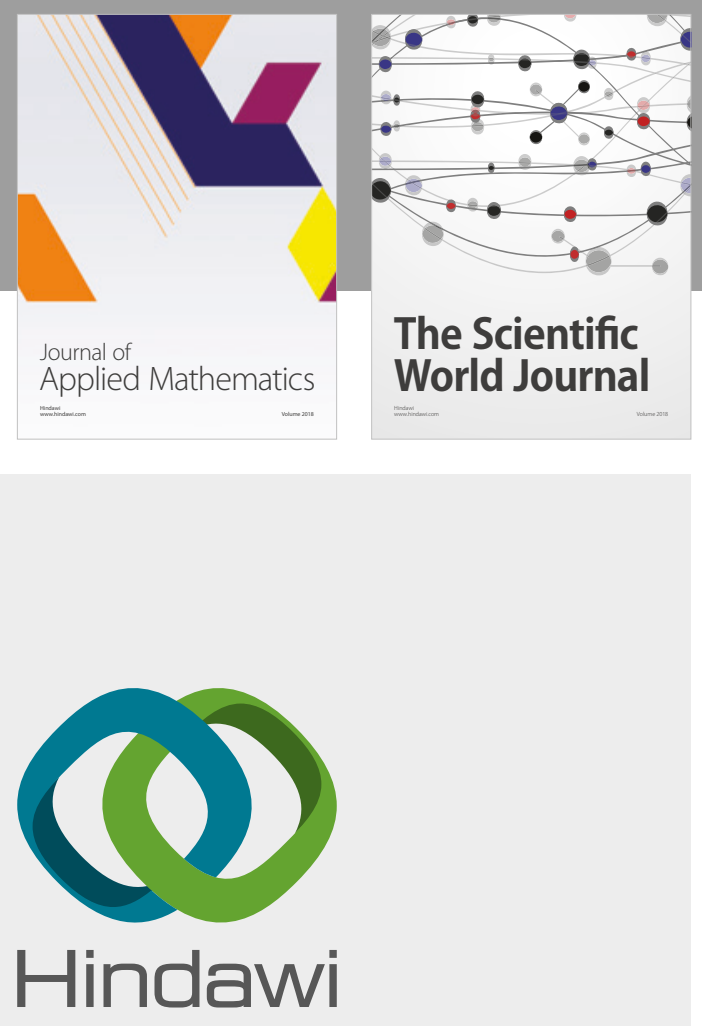

Submit your manuscripts at

www.hindawi.com

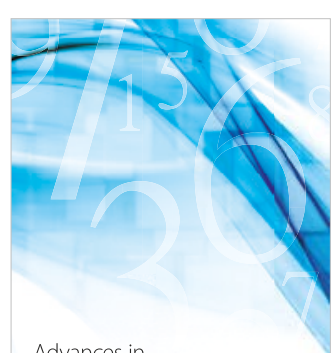

Advances in
Numerical Analysis
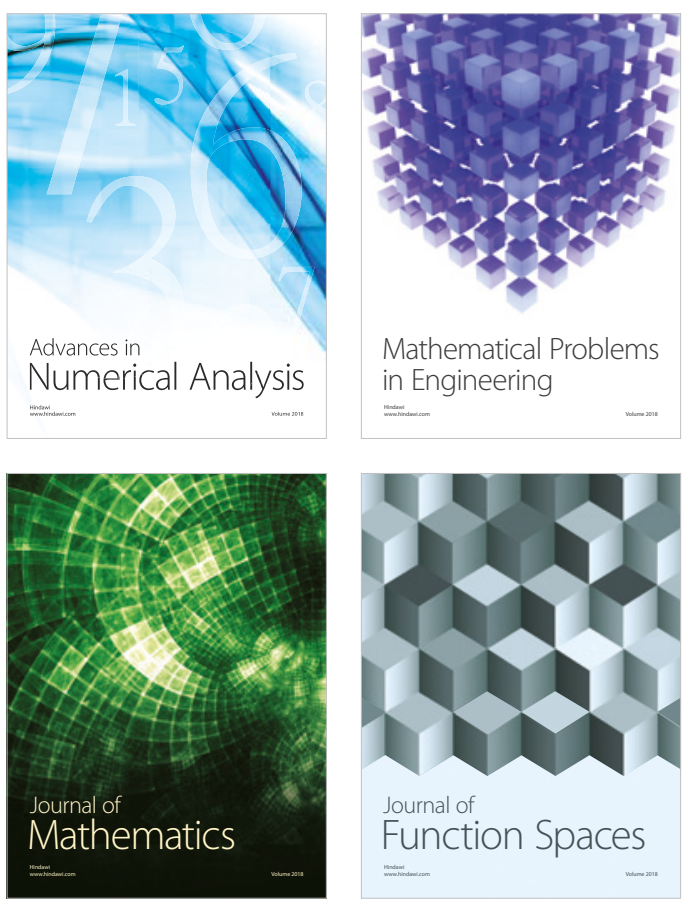

Mathematical Problems in Engineering

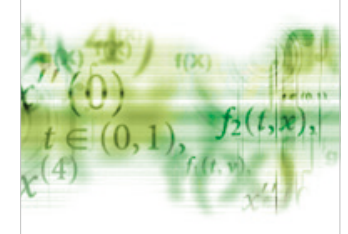

International Journal of

Differential Equations

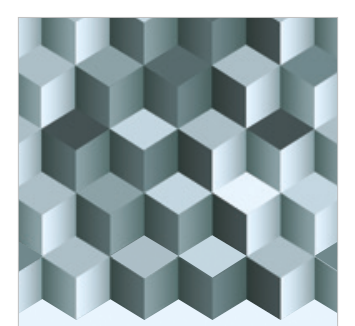

Journal of

Function Spaces

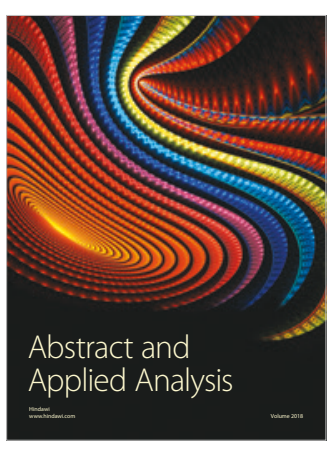

The Scientific

World Journal

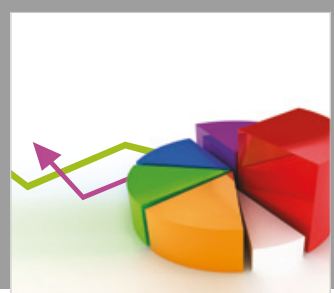

Journal of

Probability and Statistics
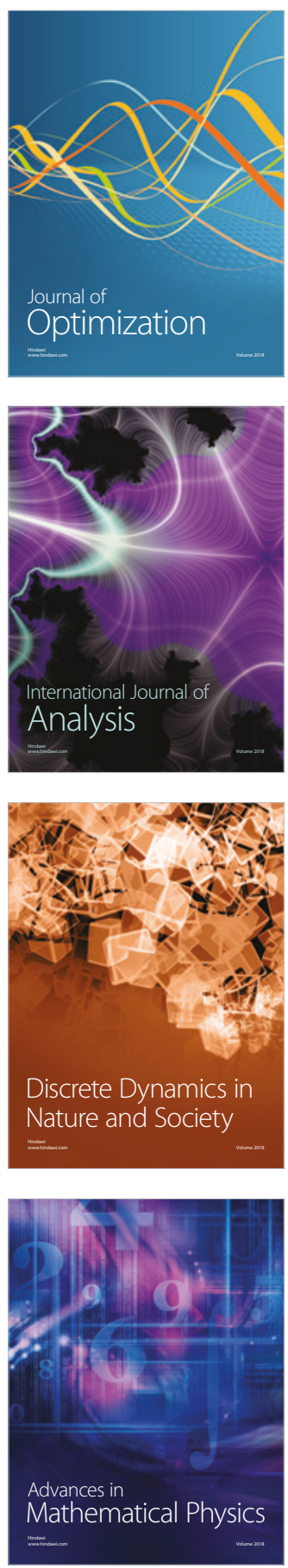